\title{
MEIO DE CULTURA KNUDSON MODIFICADO UTILIZADO NO CULTIVO IN VITRO DE UM HÍBRIDO DE ORQUÍDEA
}

\section{CULTURE MEDIUM KNUDSON MODIFIED UTILIZED IN VITRO CULTIVATION OF ORCHID'S HYBRID}

\author{
Enoque Fernandes da SILVA ${ }^{1}$ \\ Fabíola VILLA ${ }^{2}$ \\ Moacir PASQUAL ${ }^{3}$
}

\begin{abstract}
RESUMO
Os gêneros Cattleya, Laelia e Brassavola, de ocorrência natural no Brasil, são muito procurados como planta ornamental. Esta demanda cria a necessidade de desenvolver técnicas mais eficazes de propagação para atender o mercado e contribuir com a reposição de espécies ameaçadas de extinção. A origem dos explantes e o meio nutritivo onde são cultivados são fatores determinantes para o sucesso da cultura de tecidos vegetais. Objetivou-se testar concentrações do meio de cultura Knudson e vitaminas do meio MS no subcultivo da orquídea Brassocattleya Pastoral x Laeliocattleya Amber Glow. O experimento foi realizado usando-se concentrações do meio Knudson (0\%, 50\%, 100\%, 150\% e 200\%) combinadas com concentrações de vitaminas do meio MS (0\%, $50 \%, 100 \%$ e $200 \%)$. Os explantes utilizados foram plântulas oriundas da germinação in vitro, com tamanho médio de 1-1,5 cm, submetidos à uniformização em meio Knudson durante três meses. Concluiu-se que o aumento no número de brotos e folhas do híbrido não são influenciados com a adição de vitaminas MS no meio Knudson. O meio Knudson não promove aumento no sistema radicular. Vitaminas do meio MS adicionadas ao meio de cultivo são benéficas para o bom desenvolvimento das raízes.

Palavras-chave: Brassocattleya; Laeliocattleya; cultura in vitro.
\end{abstract}

\section{ABSTRACT}

The genera Cattleya, Laelia and Brassavola occur naturally in Brazil and they are world wide wanted as ornate plants and that desire for them creates the necessity to develop better propagation's techniques not only to attend the market needs but also to contribute to the replacement of the endangered species where they could become extinct. The explant's origin and the culture medium where they are cultivated are determinative factors for plants tissue culture success. The purpose was to test Knudson culture media concentrations and MS media vitamins in orchid subcultive $B C$ pastoral $\times L C$ Amber Glow. The current experiment was accomplished being used concentrations of Knudson media concentrations $(0 \%$, $50 \%, 100 \%, 150 \%$ and $200 \%$ ) combined with MS media vitamins concentrations (0\%, $50 \%, 100 \%$ and $200 \%)$. The explants used were from plantlets germinated in vitro with medium size 1 to $1.5 \mathrm{~cm}$, submitted to the uniformization in Knudson media for three months. Its concluded that the increase in number of buds and leves of hybrid is not influenced with MS vitamin addition in the culture medium Knudson. The culture medium Knudson does not promote increase to radicular system. Vitamins of the MS added to culture medium are beneficial for good development of roots.

Key-words: Brassocattleya; Laeliocattleya; in vitro culture.

\footnotetext{
${ }^{1}$ Mestre em Fitotecnia, Departamento de Agricultura, Universidade Federal de Lavras, Campus Universitário, s/n, Lavras, MG, e-mail: enorquidario@uol.com.br

2.Bolsista Pós-doc, Fundação de Amparo à Pesquisa do Estado de Minas Gerais/ Empresa de Pesquisa Agropecuária de Minas Gerais, Rua Washington Viglione, s/n, Bairro Vargedo, Maria da Fé, MG, CEP: 37517-000, e-mail: fvilla2003@libero.it

${ }_{3}^{3}$ Professor Adjunto, Departamento de Agricultura, Universidade Federal de Lavras, Campus Universitário, s/n, Lavras, MG, CEP: 37200-000, e-mail: mpasqual@ufla.br
} 
SILVA, E.F. et al. Meio de cultura Knudson modificado...

\section{INTRODUÇÃO}

As orquídeas são conhecidas não só pela sua importância ornamental, mas também industrial em função da extração de essência de baunilha do gênero Vanilla (Joly, 1967). Ocorrem em quase todas as regiões da Terra, com exceção dos pólos e desertos, sendo mais freqüentes e exuberantes nos trópicos. Entre estes se localiza o Brasil, portador de um invejável banco de germoplasma dessas plantas, tornando-se também responsável pela sua preservação (Suttleworth, 1997).

O elevado número de espécies e híbridos tropicais possibilita variadas formas, cores e flores, exploradas comercialmente em todo mundo (Hsu, 2003). Os gêneros Cattleya, Laelia e Brassavola, de ocorrência natural no Brasil (Paula \& Silva, 2001), são bastante populares e atingem altos preços no mercado interno e externo, procurados por colecionadores, orquidófilos, decoradores de ambiente e cidadãos comuns. Essa atração exercida pelas orquídeas motiva também freqüentes coletas de mudas pelos denominados mateiros, visando comercialização, constituindo ainda hoje, uma ameaça de extinção para algumas espécies.

O cultivo in vitro é uma ferramente biotecnológica importante na obtenção de plantas livres de doenças e pragas, além de propiciar a produção de um número significativo de novas mudas uniformes. Entretanto, também é usada como artifício para germinar sementes de difícil propagação pelos métodos convencionais (Pasqual et al., 1998) como é o caso das orquídeas. O crescimento e a morfogenia de algumas plântulas micropropagadas podem ser melhorados com a adição de vitaminas ao meio de cultura. Nos vegetais, estas substâncias são requeridas pelas células como catalisadores metabólicos (George, 1993).

Os fatores que mais freqüentemente determinam o sucesso da cultura de tecidos vegetais são: origem do explante e meio nutritivo onde são cultivados (Pasqual et al., 1997). Vários meios de cultura têm sido testados e um meio específico é identificado pela composição de sais minerais, enquanto as vitaminas, os reguladores de crescimento e outros suplementos orgânicos variam na concentração (Campos, 2004). A escolha do meio

depende da espécie em questão e do propósito da cultura (meristema, organogênese, embriogênese somática, cultivo ou subcultivo de explantes, etc.). No cultivo e subcultivo de plântulas do gênero Cattleya, George et al. (1987) sugerem o meio Knudson ou Reinert e Mohr. Segundo Arditti \& Ernst (1993), o meio de propagação para Cattleya, Laelia, Laeliocattleya e Brassocattleya pode ser o mesmo. Villalobos et al. (1994) sugerem o meio Vacin \& Went para Cattleya, Encyclia e Oncidium, suplementado com $25 \%$ de água de coco.

Este trabalho tem como objetivo testar variações no meio de cultura Knudson e concentrações de vitaminas do meio MS, no subcultivo in vitro da orquídea Brassiocattleya $(B C)$ Pastoral x Laeliocattleya (LC) Amber Glow.

\section{MATERIAL E MÉTODOS}

Os experimentos foram desenvolvidos no Laboratório de Cultura de Tecidos do Departamento de Agricultura da Universidade Federal de Lavras (UFLA), em Lavras, MG. Utilizou-se o híbrido intergenérico de orquídea Brassocattleya $(B C)$ Pastoral $x$ Laeliocattleya (LC) Amber Glow, selecionado pelo valor comercial dos progenitores, além da abrangência dos gêneros Cattleya, Laelia e Brassavola, na reintrodução do respectivo habitat. O cruzamento foi obtido inoculando-se o pólen da Laeliocattleya Amber Glow no estigma da Brassiocattleya Pastoral.

As sementes resultantes do cruzamento foram colocadas no meio de cultivo Knudson $100 \%$ (Knudson, 1946), acrescido de $40 \mathrm{~g} \mathrm{dm}^{-3}$ de polpa de banana e $100 \mathrm{~cm}^{3} \mathrm{dm}^{-3}$ de água de coco. Após a germinação, foram repicadas para meio idêntico ao do semeio, obtendo-se as plântulas. As plântulas com tamanho médio de $1-1,5 \mathrm{~cm}$ foram submetidas à uniformização em frascos de $250 \mathrm{~cm}^{3}$ contendo $50 \mathrm{~cm}^{3}$ de meio Knudson nas concentrações $0 \%$, $50 \%, 100 \%, 150 \%$ e $200 \%$ e $0 \%, 50 \%, 100 \%$ e $200 \%$ de vitaminas do meio MS (Murashige \& Skoog, 1962). Foram colocadas quatro plântulas por frasco com tampa plástica e vedados com parafilme, sob condições assépticas em câmara de fluxo laminar.

O meio foi solidificado com $6 \%$ de ágar, o $\mathrm{pH}$ ajustado para 5,8 , antes do processo de autoclavagem a $121{ }^{\circ} \mathrm{C}, 0,1 \mathrm{MPa}$, por $20 \mathrm{~min}$. $\mathrm{O}$ experimento foi conduzido em sala de crescimento com temperatura de $26 \pm 1{ }^{\circ} \mathrm{C}$ e fotoperíodo de $16 \mathrm{~h}$ de luz, com intensidade luminosa de 2500 candela (cd). Utilizou-se 0 delineamento experimental inteiramente casualizado com 4 plântulas por parcela e 4 repetições, totalizando 16 plântulas por tratamento.

A avaliação do experimento foi efetivada 90 dias após a instalação, analisando-se número de brotos, número de folhas, altura da plântula, número de raízes, comprimento médio do sistema radicular e peso da matéria fresca da plântula. A análise estatística do experimento foi feita utilizando o sistema Sas Institute (2003). Os dados foram analisados por meio de regressão polinomial.

\section{RESULTADOS E DISCUSSÃO}

$\mathrm{Na}$ Tabela 1 pode-se observar que houve variação para número de brotos, número de folhas, e comprimento médio do sistema radicular, tanto em relação às concentrações do meio Knudson como as concentrações de vitaminas do meio MS, utilizadas no meio de cultura. Não houve interação significativa para o uso destes produtos. Para altura das plântulas apenas as concentrações do meio Knudson promoveram efeito significativo, enquanto que em relação ao número de raízes, apenas o uso de diferentes concentrações de vitaminas do meio MS apresentou efeito significativo. 
SILVA, E.F. et al. Meio de cultura Knudson modificado...

TABELA 1 - Resumo da análise de variância para número de brotos (NB), número de folhas (NF), altura das plântulas (AP), número de raízes (NR), comprimento médio do sistema radicular (CMSR) e massa fresca da parte aérea (MFPA) do híbrido $B C$ Pastoral e $L C$ Amber Glow cultivadas em variações do meio Knudson e vitaminas do meio MS. UFLA, Lavras, MG.

\begin{tabular}{cccccccc}
\hline & \multicolumn{7}{c}{ Quadrados médios } \\
\hline $\begin{array}{c}\text { Causas da } \\
\text { variação }\end{array}$ & GL & NB & NF & AP & NR & CMSR & MFPA \\
\hline [ ] Knudson & 4 & $1,18^{*}$ & $1,42^{*}$ & $4,32^{* *}$ & $1,57^{\text {n.s. }}$ & $1,78^{* *}$ & $0,0018^{\text {n.s. }}$ \\
[ ] Vitamina & 3 & $1,32^{*}$ & $4,72^{* *}$ & $1,40^{\text {n.s. }}$ & $17,8^{* *}$ & $2,93^{* *}$ & $0,0032^{\text {n.s. }}$ \\
K x V & 12 & $0,53^{\text {n.s. }}$ & $0,51^{\text {n.s. }}$ & $1,12^{\text {n.s. }}$ & $1,43^{\text {n.s. }}$ & $0,54^{\text {n.s. }}$ & $0,0018^{\text {n.s. }}$ \\
Resíduo & 57 & 0,35 & 0,39 & 0,61 & 1,38 & 0,31 & 0,0062 \\
CV (\%) & & 32,7 & 14,9 & 24,5 & 27,4 & 22,9 & 8,3 \\
\hline
\end{tabular}

** Significativo a $1 \%$ de probabilidade. * Significativo a 5\% de probabilidade. [ ] Concentração.

Observa-se na Figura $1 \mathrm{~A}$ que o meio de cultura sem nutrientes pouco estimulou o número de brotos quando comparado com a concentração de $50 \%$ onde se obteve um máximo de 2 brotos por explante cultivado.

$\mathrm{O}$ pequeno efeito no número de brotos promovido na ausência dos nutrientes do meio Knudson pode estar associado à contaminação do ágar com sais e resíduo de reguladores de crescimento, induzindo a morfogênese de brotos adventícios (Pierik, 1987) ou devido às reservas existentes no explante, suficientes para iniciar 0 processo de formação de brotos, ou ainda, esse processo já havia iniciado no momento da inoculação.

A quantidade de nutrientes do meio Knudson parece influenciar o número de brotos emitidos pelo explante do híbrido $B C$ Pastoral $x \angle C$ Amber Glow, quando se aumenta a concentração até $50 \%$, evidenciando a deficiência em nutrientes nas concentrações próximas a $0 \%$, visto que 0 meio Knudson possui baixos teores em sais nutritivos, quando comparado com outros meios , como o MS (George, 1993).

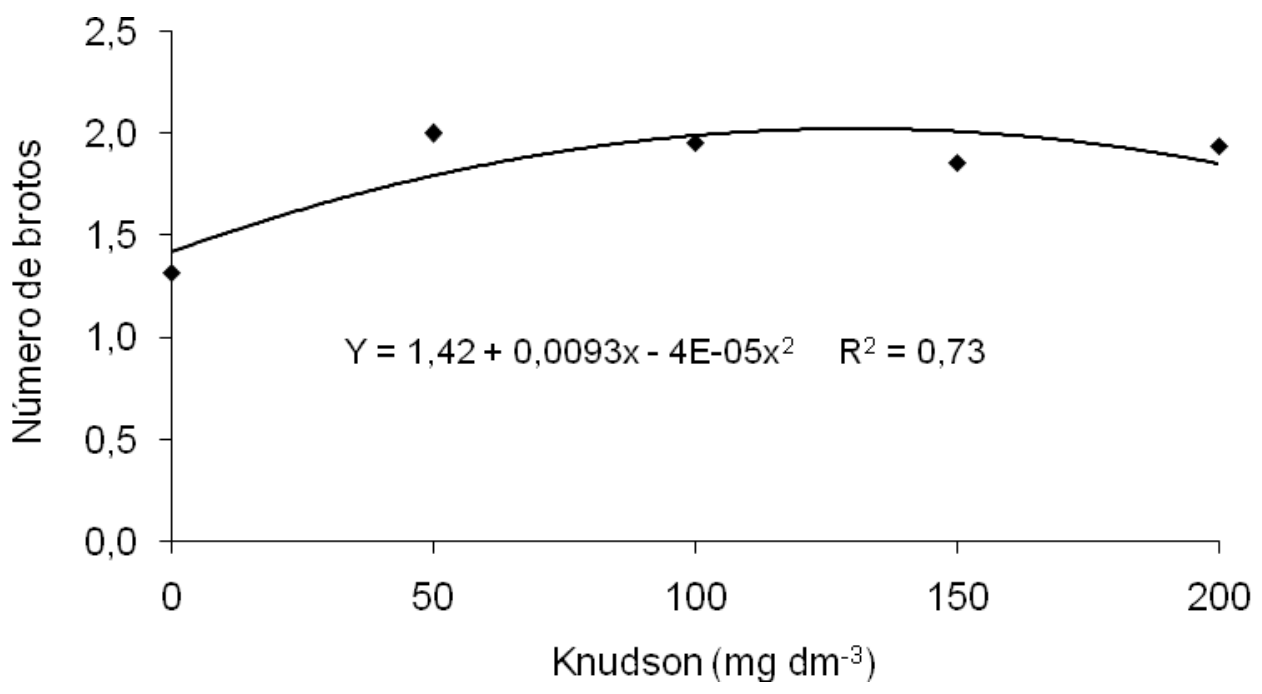

FIGURA $1 \mathrm{~A}$ - Número de brotos em plântulas de orquídea $B C$ Pastoral x $L C$ Amber Glow cultivadas em variações do meio Knudson. UFLA, Lavras, MG.

Houve influência positiva na morfogênese quando se aumentou a concentração para $50 \%$ do meio Knudson (Pierik, 1987) nas brotações adventícias. Concentrações maiores que $50 \%$ não promoveram o número de brotos, havendo tendência de estabilização na média de 2 brotos, parecendo que o estímulo vai para o crescimento do explante ou para o alongamento do sistema radicular. $\mathrm{Na}$ Figura $1 \mathrm{~B}$ observa-se que a concentração de $50 \%$ de vitaminas do meio MS promoveu a melhor resposta para número de brotos, com média máxima de 2,05 brotos por explante. 
SILVA, E.F. et al. Meio de cultura Knudson modificado...

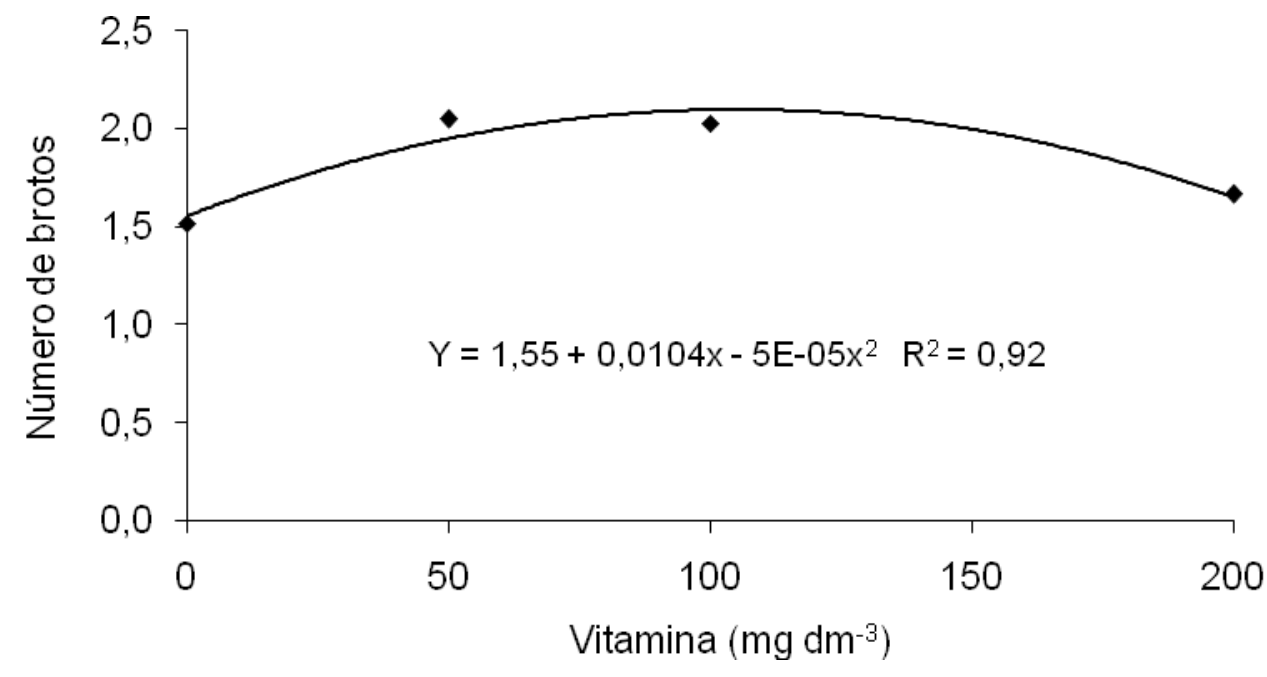

FIGURA 1B - Comprimento médio do sistema radicular em plântulas de orquídea $B C$ Pastoral $\times L C$ Amber Glow cultivadas em variações do meio Knudson suplementado com diferentes concentrações de vitaminas do meio MS. UFLA, Lavras, MG.

Vários autores estudando o crescimento in vitro de plântulas de orquídea, verificaram que a redução em até $50 \%$ dos sais do meio de cultivo MS não compromete o crescimento de Oncidium varicosum e Miltonia flavescens (Rego-Oliveira et al., 2003; Muller et al., 2007). Porém híbridos de $B C$ Pastoral inocence $\times$ Cattleya loddigesii $\times L C$ Luminosa e BLC Arrow gold $x$ Pot Red crab tiveram um aumento no número de suas brotações em meio de cultura Knudson sem a adição de vitaminas do MS (Figueiredo et al., 2007).

O número de folhas foi influenciado pelas concentrações do meio Knudson e vitaminas do meio MS de maneira diversa. Na Figura 2A, podese observar que a quantidade de folhas aumenta gradativamente até 0 ponto de máxima da concentração do meio Knudson, provavelmente pelo aumento da disponibilidade de nutrientes. Como o incremento não foi significativo para número de folhas do híbrido estudado, pode-se utilizar a concentração $100 \%$. A diminuição no número de folhas em concentrações acima da citada pode estar relacionada com o favorecimento do crescimento de folhas pré-existentes no explante em detrimento da morfogênese (George, 1993).



FIGURA 2A - Número de folhas de plântulas de orquídea BC Pastoral x $L C$ Amber Glow cultivadas em variações do meio Knudson. UFLA, Lavras, MG. 
SILVA, E.F. et al. Meio de cultura Knudson modificado...

$\mathrm{Na}$ Figura 2B observa-se que o aumento gradativo nas concentrações das vitaminas do meio MS reduziu a emissão de novas folhas. As vitaminas do meio MS influenciaram como catalisadores metabólicos no crescimento de órgãos, confirmando sua função de estimular o crescimento geral das plântulas (George, 1993). Pode-se inferir que as vitaminas do meio MS não são necessárias seja para promover número de brotos ou para número de folhas.

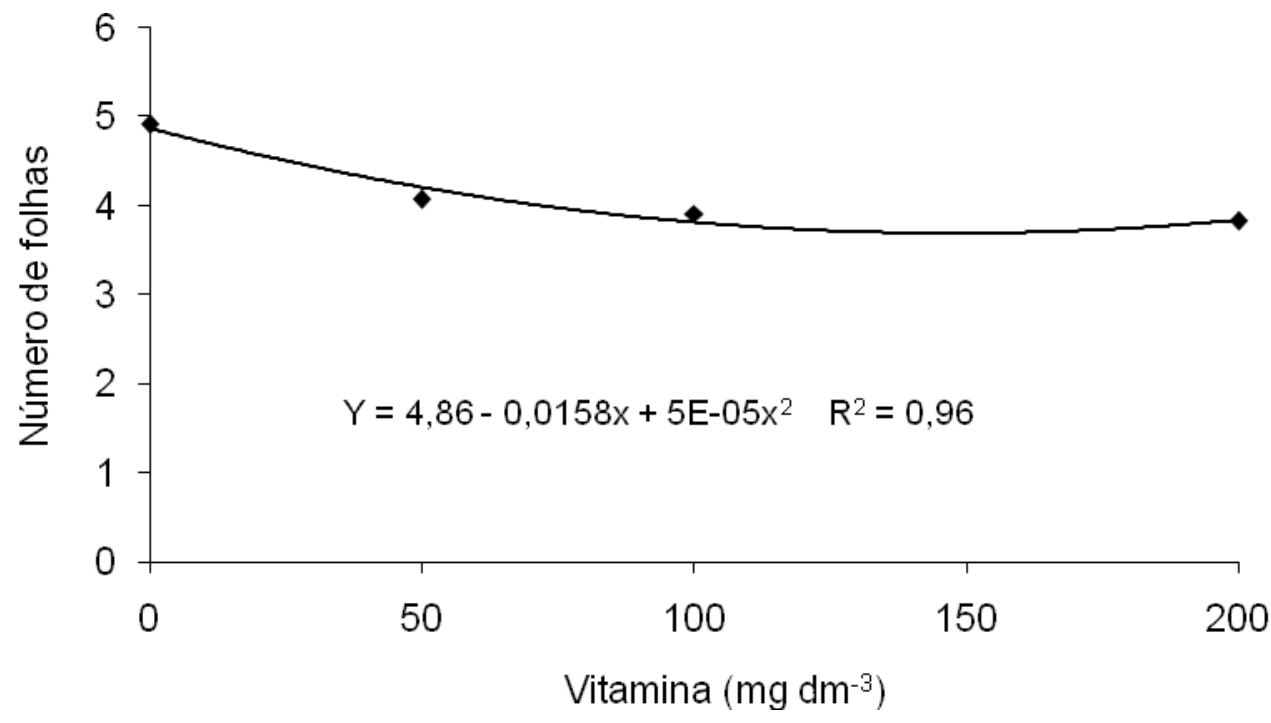

FIGURA 2B - Número de folhas de plântulas de orquídea $B C$ Pastoral x $L C$ Amber Glow cultivadas em variações do meio Knudson suplementado com diferentes concentrações de vitaminas do meio MS. UFLA, Lavras, MG.

As proporções do meio Knudson influenciaram positivamente a altura das plântulas até o ponto máximo, sendo uma influência direta do aumento no teor de nutrientes (Figura 3). Carlucci et al. (1989) afirmam que os gêneros Cattleya e Laelia são exigentes em zinco (Zn). O $\mathrm{Zn}$ desempenha importante função no metabolismo de crescimento das plântulas e, segundo alguns autores, existe necessidade do aumento da disponibilidade desse nutriente em meio de cultura para melhor crescimento de híbridos (Araujo, 2004; Figueiredo et al., 2007). Após atingir o valor máximo, a altura das plântulas decresceu, provavelmente em função da



FIGURA 3 - Comprimento da parte aérea de plântulas de orquídea $B C$ Pastoral x $L C$ Amber Glow cultivadas em variações do meio Knudson. UFLA, Lavras, MG. 
SILVA, E.F. et al. Meio de cultura Knudson modificado...

Uma característica marcante das orquídeas epífitas no estádio juvenil é a emissão de novas raízes, se comparado com o sistema radicular fasciculado das monocotiledôneas terrestres e este fato pode ter agravado a absorção por difusão pela menor área de contato do sistema radicular do híbrido estudado.
À medida que se aumentaram as concentrações de vitaminas do meio MS, maior quantidade de raízes foi formada (Figura 4), aumentando a área de contato raiz/substrato, refletindo em maior absorção dos nutrientes. Desta forma, as vitaminas do meio MS contribuíram no aumento do número de raízes.

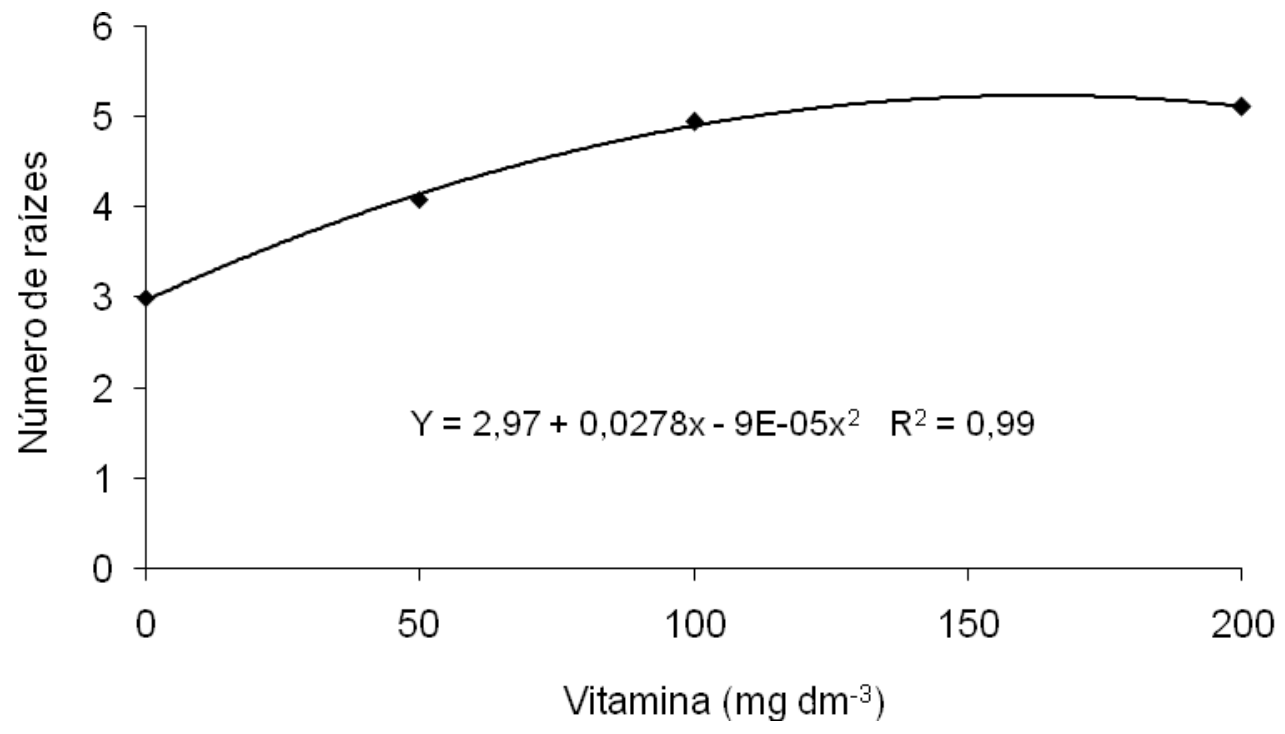

FIGURA 4 - Número de raízes de plântulas de orquídea $B C$ Pastoral x $L C$ Amber Glow cultivadas em variações do meio Knudson suplementado com diferentes concentrações de vitaminas do meio MS. UFLA, Lavras, MG.

Num substrato com deficiência de nutrientes, aumentar o comprimento das raízes é uma maneira da plântula buscar os nutrientes necessários ao seu desenvolvimento mesmo que isto implique em gasto de reservas. Na Figura $5 \mathrm{~A}$ observa-se que a ausência do meio Knudson influenciou o comprimento médio do sistema radicular desta maneira.

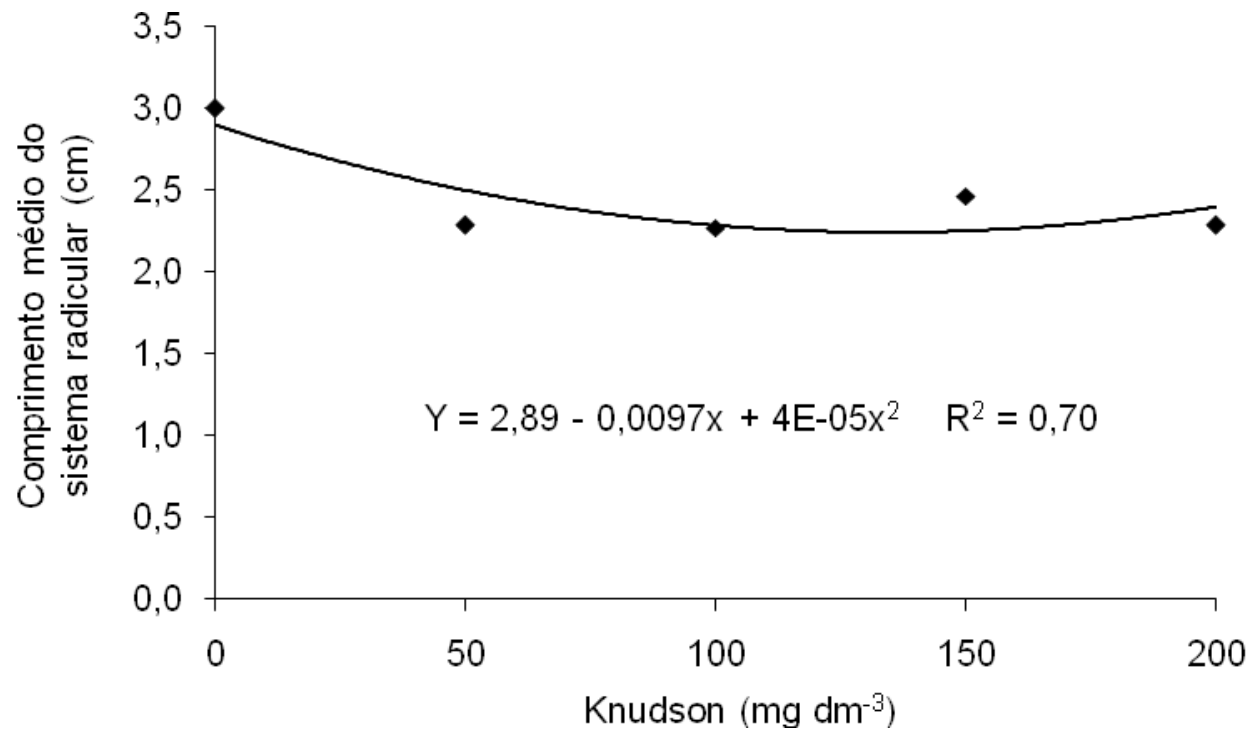

FIGURA 5A - Comprimento médio do sistema radicular de plântulas de orquídea $B C$ Pastoral x $\angle C$ Amber Glow cultivadas em variações do meio Knudson. UFLA, Lavras, MG. 
SILVA, E.F. et al. Meio de cultura Knudson modificado...

À medida que aumenta a concentração até próximo de $100 \%$, diminui o comprimento médio do sistema radicular. As concentrações de vitaminas do meio MS influenciaram de maneira positiva o crescimento das raízes (Figura 5B), até o ponto de máxima. Evidencia-se assim que, para promover o comprimento médio do sistema radicular, o meio Knudson é inibitório e as vitaminas do meio MS são benéficas.

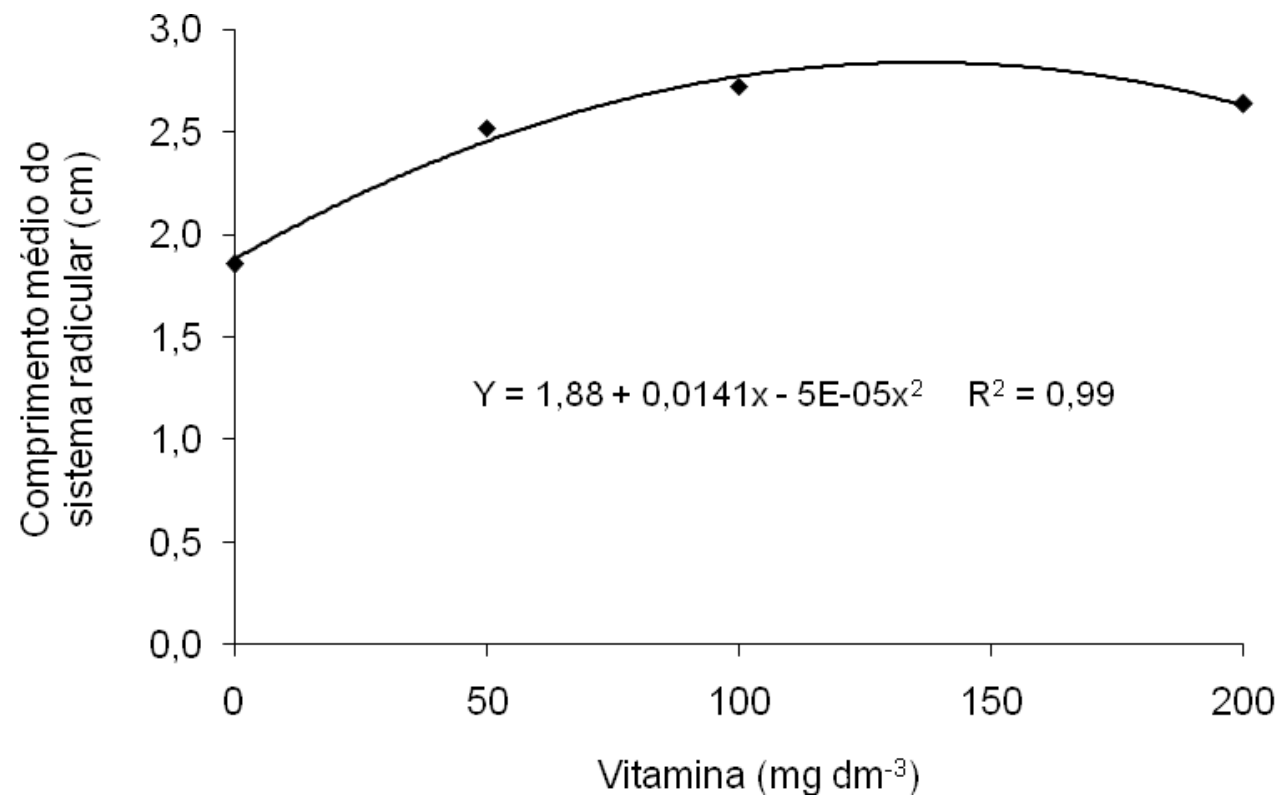

FIGURA 5B - Comprimento médio do sistema radicular de plântulas de orquídea $B C$ Pastoral $\times L C$ Amber Glow cultivadas em variações do meio Knudson suplementado com diferentes concentrações de vitaminas do meio MS. UFLA, Lavras, MG.

As pesquisas envolvendo diferentes vitaminas parecem ser específicas para cada espécie e talvez para diferentes cultivares da mesma espécie, dependendo também do tipo de explante (Caldas et al., 1998). Além disso, o efeito benéfico da inclusão de determinada vitamina no meio de cultura dependerá, em grande parte, da capacidade de biossíntese de cada um nos tecidos ou órgãos cultivados. Ainda segundo estes autores, dos resultados já obtidos em estudos envolvendo o emprego de vitaminas, o que mais se destacou foi 0 efeito benéfico ou mesmo a dependência absoluta de muitas culturas para a tiamina.

\section{CONCLUSÕES}

Concluiu-se que o aumento no número de brotos e folhas do híbrido não são influenciados com a adição de vitaminas MS no meio Knudson. O meio Knudson não promove aumento no sistema radicular. Vitaminas do meio MS adicionadas ao meio de cultivo são benéficas para o bom desenvolvimento das raízes.

\section{REFERÊNCIAS}

1. ARAUJO, A. G. Crescimento in vitro e aclimatização de plântulas de orquídea. 2004. 73 f. Dissertação (Mestrado em Fitotecnia) - Universidade Federal de Lavras, Lavras, 2004.

2. ARDITTI, J.; ERNST, R. Micropropagation of orchids. New York: John Wiley, 1993. $682 \mathrm{p}$

3. CALDAS, L. S.; HARIDASAN, P.; FERREIRA, M. E. Meios nutritivos. In: TORRES, A. C.; CALDAS, L. S.; BUSO, J. A. (Ed.). Cultura de tecidos e transformação genética de plantas. 2.ed. Brasília: EMBRAPA-SPI, v. 2, p. 864, 1998.

4. CAMPOS, D. M. Cultura in vitro simplificada. O mundo das orquídeas, n. 36, p. 52-53, 2001.

5. CARLUCCI, M. V.; HAAG, H. P.; BELLOTE, A. F. J. Composição química e extração de nutrientes por cinco espécies de Orchidaceae. In: HAAG, H. P.; MINAMI, K.; LIMA, A. M. L. P Nutrição mineral de algumas espécies ornamentais. Fundação Cargill. p. 254-267, 1989.

6. FIGUEIREDO, M. A. et al. Variações no meio de cultura sobre o crescimento in vitro em híbridos de orquídea. Revista Brasileira de Biociências, v. 5, supl. 2, p. 294-296, 2007.

7. GEORGE, E. F. (Ed.). Plant propagation by tissue culture. pt. 1. - The technology. 2. (Ed.). Edington: Exegetics, 1993, p. 574.

8. GEORGE, E. F.; PUTTOCK, D. J. M.; GEORGE, H. J. Plant culture media: formulations and uses. England: Exegetics, 1987. v. 1, p. 567. 
SILVA, E.F. et al. Meio de cultura Knudson modificado...

9. HSU, C.C. Protocorm-like body induction and plant regeneration from etiolated leaves of in vitro Phalaenopsis. 2003. 88 p. Tese (Doutorado em Agricultura) - Institute of Tropical Agriculture and Intl Cooperation, University of Science \& Technology, Pingtung, 2003.

10. JOLY, A. B. Botânica: Introdução à taxonomia vegetal. 4. ed. São Paulo. Editora Nacional, 1967. 730. p.

11. KNUDSON, L. A new nutrient solution for the germination of orchid seed. American Orchid Society Bulletin, v. 14, p. 214- 217, 1946.

12. MULLER, T. S. et al. Crescimento in vitro e aclimatação de plântulas de Miltonia flavescens Lindl. Revista Brasileira de Biociências, v. 5, supl. 2, p. 252-254, 2007.

13. MURASHIGE, T.; SKOOG, F. A revised medium for rapid growth and bio assays with tobacco tissue cultures. Physiologia Plantarum, v. 15, n. 3, p. 473-497, 1962.

14. PASQUAL, M.; HOFFMANN, A.; RAMOS, J D. Cultura de tecidos vegetais: tecnologia e aplicações. Introdução fundamentos básicos. Lavras-MG: UFLA/FAEPE, 1998. $159 \mathrm{p}$.

15. PASQUAL, M. et al. Cultura de tecidos vegetais: tecnologia e aplicações. Meios de cultura. Lavras-MG: UFLA/FAEPE, 1997. $127 \mathrm{p}$

16. PAULA, C. C.; SILVA, H. M. P. Cultivo prático de orquídeas. 2. ed. Viçosa: UFV, 2001. 63 p.

17. PIERIK, R. L. M. In vitro culture of higher plants. Dordrecht: Martinus Nyjhoff Publishers, 1987. $344 \mathrm{p}$.

18. REGO-OLIVEIRA, L. V. et al. Influência da fonte e concentração de carboidrato no crescimento vegetativo e enraizamento in vitro de Oncidium varicosum Lindl. (Orchidaceae). Semina: Ciências Agrárias, v. 24, n. 2, p. 265-272, 2003.

19. SAS INSTITUTE. User's guide version 8.1. Cary, 2003.

20. SUTTLEWORTH, F. S.; ZIM, H. S.; DILLON, G. W. Orquídeas: guia dos orquidófilos. 7. ed. Rio de Janeiro: Expressão e Cultura, 1997. $158 \mathrm{p}$.

21. VILLALOBOS, A. L.; MUÑOZ, J. M.; SOSA-MOSS, C. Cultivo de tejidos de orquideas: Cattleya, Encyclia, Oncidium y Stanhopea. Revista Chapingo. Série Horticultura, v. 1, n. 1, p. 58-62, 1994.

Recebido em 05/08/2009

Aceito em 05/05/2009 